\title{
An Assessment of the Impact of Parental Separation on Social Attitudes of Secondary Schools' Adolescents in Ondo State
}

\author{
Dr. Olorunfemi-Olabisi, F.A. \\ Department of Guidance and Counselling, Faculty of Education, \\ Adekunle Ajasin University, Akungba-Akoko, Nigeria. \\ Olabisiolorunfemi53@yahoo.com
}

Doi:10.5901/jesr.2014.v4n6p325

\begin{abstract}
This study investigated the impact of parental separation on social attitudes of adolescents' students of secondary school in Ondo State. The study adopted a descriptive research design of the survey method. Two hundred and forty (240) adolescent students were randomly selected from 6 senior secondary schools. One hundred and twenty (120) students each were selected from homes with intact and separated parents respectively. The selected students were the samples used for the study. Two research hypotheses were generated and tested for the study. A self-constructed instrument titled "Parental Separation and Social Attitude of Adolescents Questionnaire" (PSSAAQ) was used to collect data from the respondents for the study. The data collected were analyzed using t-test. All the hypotheses were tested at 0.05 level of significance. The findings revealed that there was a significant difference in the social attitudes of adolescent students from homes with separated parents and those from homes with intact parents. This implies that the parents have a vital and substantial role to play in the development of the child's attitudes mainly to avert deviant behaviours. Therefore, social attitude of any child is dependent of parental care. Based on the above findings, some recommendations were made.
\end{abstract}

Keywords: social attitude, adolescent, deviant behaviour, parental separation, intact home.

\section{Introduction}

The development of human is commonly described in terms of periods. Approximate age ranges are given for the periods to provide a general idea of when they begin and end. Larson (2002) argued that adolescence development (a period of transition between childhood and adulthood) involves biological, cognitive, and social-emotional changes.

According to Bamisaye (1998), the family is the bedrock of attitude and value formation, both positively and negatively. The family is a primary socializing agent for the child both overtly and covertly. The child first learns his social roles through imitation of the older siblings and later, through internalized patterns and principles of behavior in the family. Bamisaye (1998), referred to the family as the place where the child first learns the appropriate behavior patterns, values, attitudes, norms and folkways of the society. All these are known to influence the socialization process in significant ways resulting in different patterns of behavior and consequently in their personality.

The values and attitudes, customs and traditions of the society are taught to young children in the family. Therefore, social behavior is learnt in the family. Attitudes and values are easier learnt under a conducive family environment. It is therefore within the family that the child gets prepared for the outside world.

Attitude is concerned with an individual's way of feeling, thinking and behaving and this has serious implications for the child, the parents, the immediate social group and the society at large . In other words, a person attitude is reflected through his/her behavior.

Bandura (1977) identified the causes of behaviour in terms of relationship with others being external or internal. Internal causes are perceived to be ones genetic background and personality traits. While external causes are perceived to be related to one's physical environment and social setting. Internal causes are supposed to represent factors that are completely under the control of or within the individual while the external causes are supposed to be beyond the control or outside of the individual.

Tittley (1990) argued that the human dignity begins in the home. That the family is the breeding ground of all interpersonal relationships, the basic sociology unit where personal character is first molded and self-identity first formed. Unfortunately, instability is present in many homes today due to parental separation which often affect the social attitudes of the child. 
Individuals are generally predisposed to certain styles of social interaction and self- soothing. The general development of the adolescent has implications on their physical, psychological and social behaviors. Physical development has a psychological effect on the attitude, interest, interaction and their heterosexual relationship.

Social development, the advent of puberty, ushers in great physical changes in appearance and attention seeking in the adolescents' environment and the society at large. The adolescents now judges how he relates with people in terms of his acceptance and ability to establish relationships in his peer group. The type of group with which the adolescent associates determines to a considerable extent the type of individual he will develop to be.

Children social stability could be largely enhanced by the stability of the parents and siblings in their immediate environment. In a stable, supportive home, the child grows up to learn that the world is a safe and predictable place where competent, caring adults help to navigate challenges. It should be noted that marital instability has much story to tell in the lives of the adolescent because it gives them room to be free when there is no one to control them. Parental divorce or separation leads to many changes in the development of the child.

Forman and Davies (2003) maintained that at adolescence, the individual is getting developed psychologically to cope and bear with stress and tensions which they are faced with. They argued that ability to bear with stress and tensions the adolescents are faced with a lot of pressure and tensions. A child biological temperament plays a vital role in the eruption and resolution of separation. The studies of Park and Kim (2001) maintained that individuals are generally predisposed to certain styles of social attitudes and interaction. The study is to assess on the impact of parental separation on social attitude of secondary school students.

According to Ekundayo and Oyeniyi (2008) and Adebule (2012), the society is tackling with many behaviour problems of the adolescent students, which include truancy, disobedience, drug addiction, smoking, flirting, stealing, and armed robbery, violent behavior and demonstration, examination malpractice, cultism and thugery . Omotosho, Adeniyi and Bada (2010) in addition to the above mentioned, also viewed sex abuse, sex activities, indiscriminate sex, homosexual (gay and lesbianism ) as part of behaviour problems prevalent among Nigerian secondary school adolescent students.

Adebowale (2006) in a study on the social behavior of adolescents as it affects their moral behavior observed that the type of home which the adolescent comes from, determine to a considerable extent, the type of attitude which he will develop to exhibit. The study revealed that the co-parental relationship of mother and father provides children with a model of adjusting, communicating, negotiating, and compromising together.

Marital instability has a long and lasting impact on lives of any adolescent. The state of the home or the marital status of adolescent parents speaks volume about the life of the child. Separated homes have been found as a crucial factor causing anti-social problems among youths. Olusola (2008) believed that the highest incidence of adolescents whose parents are living separately may become way-ward, unruly, or take to sexual misconduct as a way of searching for affection which was lacking in their unhappy parental home. Many researches (Hayes, 1987; William, 2002; Miller and Webb, 1995) have shown that immoral behavior are prevalent among adolescents who are from unstable or separated family, with less adequate parental training on their moral and social attitudes.

Park and Kim (2003) argued that the mother traditionally' play substantial role in the care of the family. The mothers' cares for them, listens to their problems and provide solutions. Mothers are very important in ensuring a happy childhood and meaningfully adult life for their children. The parent child relationship studies indicate that a father can contribute uniquely to the development of the child independently of the mother's contribution. However, when issues on factors such as emotional, intelligence, self-esteem, competence and confidence come up, the father cannot be replaced easily by the mother.

This study intends to assess parenting impact on the social attitudes of adolescent students in separated and intact homes.

\section{Research Design}

The study is a descriptive research of the survey method. Questionnaires were used to collect data from the samples on their social attitudes.

\section{Research Instrument}

A self-constructed questionnaire titled "Parental Separation and Social Attitudes of Adolescents Questionnaire (PSSAAQ) were administered to collect data from the respondents for the study. The instrument was divided into two 
sections, A and B. Section A deals with the personal data of the respondents like Name of school, age, class, parental status and sex, while Section B consisting of 20 items solicited for information on parental separation and social attitudes of the students.

\section{Validity of the Instrument}

The instrument was validated by test experts in test and measurement in the Faculty of Education in the University and the researcher. The instrument was subjected to the Cronbach Alpha which yielded a coefficient value of 0.82 and thus ensured to meet face and content validity.

\section{Reliability of the Instrument}

The reliability of the instrument was established through test- re-test method. The instrument was administered twice with an interval of two weeks on 20 students that were not part of the sample The two sets of scores from the responses were correlated using Pearson Product Moment Correlation method with a reliability coefficient of $r=0.87$.

\section{Method of Data Collection}

The questionnaire was administered by the researcher on the students selected for the study in the selection schools. Out of the three hundred (300) questionnaire administered on the students, two hundred and forty (240) questionnaires selected from adolescents from intact parents and separated parents were used for the study. One hundred and twenty questionnaires were selected from each home.

\section{Research Hypothesis}

1. There is no significant difference in the social attitudes of secondary school adolescent students from intact and separated homes.

2. There is no significant difference in the social attitude of male and female secondary school adolescent students from parental separated home.

\section{Data Analysis and Results}

The two hundred and forty (240) questionnaires were administered and the data collected were analyzed using t-test statistic. To determine the significance of the generated hypotheses, the hypotheses were tested at 0.05 level of significance.

\subsection{Hypothesis One}

There is no significant difference in the social attitude of secondary schools' adolescent students from intact and separated homes.

Table 1: Summary of t-test in the social attitude of secondary schools' adolescent students from intact and separated homes.

\begin{tabular}{|l|c|c|c|c|c|c|}
\hline Variables & No & X & SD & Df & t-cal & t-crit \\
\hline Separated Home & 120 & 70.21 & 21.14 & 138 & 5.62 & 1.960 \\
\hline Intact Home & 120 & 72.15 & 22.15 & & & \\
\hline
\end{tabular}

Table 1 showed that the $t-c a l=5.62$ and $t-c r i t i c a l=1.960$ at $d f=238(P<0.05)$. Since $t-c a l$ is greater than $t-c r i t i c a l$, the hypotheses which states that there is no significant difference in the social attitude of secondary schools' adolescent students from intact and separated homes is therefore rejected. 


\subsection{Hypothesis Two}

There is no significant difference in the social attitude of male and female secondary schools' adolescent students from parental separated home.

Table 2: Summary of t-test on the social attitude of male and female secondary schools' adolescent students from parental separated home

\begin{tabular}{|l|c|c|c|c|c|c|}
\hline \multicolumn{1}{|c|}{ Variables } & No & $\mathrm{X}$ & $\mathrm{SD}$ & $\mathrm{Df}$ & $\mathrm{t}_{\text {cal }}$ & $\mathrm{t}_{\text {_tab }}$ \\
\hline Male & 58 & 74.56 & 21.14 & 118 & 0.128 & 1.960 \\
\hline Female & 62 & 76.02 & 23.11 & & & \\
\hline
\end{tabular}

Table 2 above indicated that the $t-c a l=0.128, t-c r i t c a l ~ 1.960, d f=118(P<0.05)$. Since the $t-c a l(0.128)$ is lesser than $t-$ critical (1.960), the hypothesis which states that there is no significant difference in the social attitudes of male and female secondary school adolescent students from parental separated home is not rejected.

\section{Discussion}

The results obtained from this study indicate that separation of parents has an adverse effect on the personality development of the child generally, and on the childs' social attitude specifically.

Hypothesis one which states that there is no significant different in the social attitude of secondary schools' adolescent students from intact and separated homes was rejected. The findings indicate that children of separated families are at risk of behavior problems including bedwetting, withdrawal, aggression, sexual abuse, delinquencies and other anti-social behaviours. This is in agreement with the findings of Rodgers and Pryor (2005) who affirmed that parents have important roles to play especially in the molding of the child's behavior .

The hypothesis which states that there is no significant difference in the social attitudes of male and female secondary school adolescent students from parental separated home is not rejected.

It was also affirmed in the study that parental separation has led to high level of social decadence among adolescent males and females from parental separated homes than their counterparts from intact parents. Data collected from male and female secondary school students age 15 and 18 years on their sexual behaviors as it relates to their social life, indicates that male and female adolescents from separated parents are found mainly involved in sexual immorality.

This is in consonant with Adebowale (1993) that immoral behaviors are prevalent in the lives of male and female adolescents who are from unstable family. This could be as a result of less adequate parental training, thus, their deviant behavior was not properly dealt with. Also, in most cases, adolescents from separated homes spend much of their time and days with their peers, thus behaving in like manners.

However responses point towards a higher level of deviant behaviours among male and female from separated homes. Certainly, a child living without his or her father will receive less attention than a child living with both parents.

\section{Conclusion}

It can be concluded from the findings of this study that deviant behavior is prevalent among secondary school adolescent students in Ondo State. It was also concluded that:

The level of involvement of students from separated homes in delinquent social attitudes is virtually higher than students from homes where parents live together.

Parental separation has great impact on development of social attitudes of adolescent students in secondary school.

The social behaviours of secondary school adolescents in homes where parents live together differ from the social attitudes of those students from separated parents.

The social attitudes of male and female secondary schools' adolescent students from separated homes are virtually the same.

Finally, parental separation has a negative impact on the social attitudes of adolescents since the value and attitudes, the customs and traditions of the society are taught to young children in the family by their parents. Therefore, 
there is connection between parental separation and social attitudes of secondary school adolescents students. Students from separated homes are likely more disposed to negative social attitudes than students from parents living together.

\section{Recommendations}

Based on these findings the following recommendations were made:

The development of acceptable social attitudes in the society enhances the acceptability of the child by members of his immediate environment. The parents have a vital role to play in the development of the acceptable social attitudes of the child from cradle. The adolescent is not complete without the physical and social development that they have to undergo, but if not properly handled, it can mar their behavior.

Separation or divorce can have a damaging effect on children (especially at the adolescent stage of life), therefore, parents should endure whatever hardship or stress in order to nurture their children since separation could lead adolescents to formation of anti-social behavior and attitudes.

Parents should counsel their children always and monitor the peer group they relate with.

\section{References}

Adebowale, I. O. (2006). Parental background, influence and immoral behaviour among secondary school students. An Unpublished work of National Teachers Institute, Kaduna.

Adebule, S.O. (2012). Moral discipline and academic performance of secondary school students in Ekiti State of Nigeria. Journal of Ireland International Conference on Education.

Bamisaye,R.A. (1998). Sociological Foundations of Nigeria Education. (An Introduction). Ibadan: AMD Publishers, pp 48-57.

Bandura, (1997). Self-Efficacy. New York: W. H. Freeman

Ekundayo, H.T. and Oyeniyi, P.(2008).issues in examination malpractices in Nigerian educational system. Journal of educational foundations and management. 6 (1): 158-166.

Forman, E.M. and Davies P.T. (2003). Family instability and young adolescent mal-adjustment. The mediating effect of parenting quality and adolescent appraisal of family security. Journal of clinical, child and adolescent Psychology, 32, 94-105.

Hayes, C. (1987). Risking the future: Adolescent Sexuality and Child Bearing. Washington DC: Natural Academic Press.

Larson, R.W. (2002) Towards a psychology of positive youth development. In J.W.Sandtrock (10 th ed.) Adolescence. New York: McGraw-Hill

Miller, S. M. and Webb, R. (1995). Child Psychology, the Modern Science, (2nd Ed.). U.S.A. Von Hoffman Press.

Olusola, E. A. (2008). Socio-psychological factors as predictors of delinquent behaviours among secondary school adolescents in Ondo State. African Journal for Psychological study of social issues 2(4)210-218.

Omotosho, B.A, Adeniyi, W.O. and Bada, T. (2010). The influence of knowledge of HIVIAIDS on behavior change among undergraduate students of Faculty of Education, Obafemi Awolowo University, Ile Ife; The counselor, 27;7-20.

Park, Y. S. and Kim, U. (2003). The Influence of Parent child Relationship on Achievement Motivation and academic achievement among Korean adolescents: An Indigenous Psychological analysis. Korean Journal of Youth Studies 10, 139-165.

Park, Y. S. and Kim, U. (2001). Influence of environmental and psychological factors on school violence: Comparative analysis of High School Students and Adolescents. Korean Journal of Educational Psychology, 15,25-52.

Rodgers,B. and Pryor, J.(2005). Divorce and separation: The outcome for children. Joseph Rowntree Foundation. http://www.jrf.org.uk/ fmowledg /foundations/spr6108.asp.

Tittley,M.(1990).Youth from broken homes. http//www.sonlifeafrica.com/model/brhome.htm. 
ISSN 2239-978X

ISSN 2240-0524
Journal of Educational and Social Research MCSER Publishing, Rome-Italy
Vol. 4 No. 6 September 2014 